\title{
The Great Themes of the Qur'an
}

By Jacques Jomier. London: SCM Press Ltd, 1997.

Jacques Jomier states that this book was written at the request of some nonMuslims living and working in the Muslim world, who were daunted by the seemingly "impenetrable" and "closed" nature of the Qur'an - a statement that is rather surprising when one considers that, for several decades now, contact with the Qur'an has made Islam the fastest growing religion in the Western world. Note especially the author's statement that "Islam is the Qur'an" and that, according to Christian estimates, Islam will be more practiced in Britain than Christianity by the year 2006 .

A superficial glance at the text gives the reader the impression that this is an objective piece of work, but on closer examination the author's preconceptions and personal bias become obvious. In the introduction, for example, Jomier describes his colleagues - the non-Muslims living with Muslims, for whom the book is intended - as having "persevered with their project" (p. ix), and that "before the present work was written, it was explored and discussed in two or three closed groups and many of the observations it contains were suggested by this experience" (p. x). He also defines their strategy in both a patronizing and an evangelical tone, saying, "We will succeed only if we are prepared to listen to them [Muslims] tactfully, without taking their positions as hard and fast, knowing that there are different tendencies among them that are capable of development" (p. xi). 
Bearing this in mind, it becomes quite easy to spot the subtly condescending statements and offensive remarks that follow lavish words of praise and fascination with the Qur'an and Muslims throughout the text. For example, the author says, "Hence the moral, edifying aspect of these Qur'anic stories. There is nothing comparable to the impact of their biblical counterparts in which the faithful are confronted with human reality, with its good and bad sides. ... The Muslim is deeply shocked when he finds stories in the Bible that are all too human" (p. 82); "The Qur'an contains a core of assertions that it repeats over and over again. The rest is allusive, remaining deliberately vague so as not to distract the attention" (p. 4); and "A simple Muslim once told me that when the preacher at the mosque speaks of Jesus, it is usually to emphasize his miracles. The Qur'an gives hardly any details about them" (p. 89).

The book consists of nine major themes, a conclusion, an index of Qur'anic references, and a general index.

In the first chapter, titled "What Is the Qur'an?" the author tries to present a brief history of mankind as discussed in the Qur'an. Unable to detach himself from the Judeo-Christian account of human history, he claims that "the history of humanity began with the disobedience of the first couple and their expulsion from the earthly paradise" (p. 1), although it is quite obvious to any reader of the Qur'an that this was not the beginning. The second Judeo-Christian implant in his account of what the Qur'an says is the notion of an earthly paradise, since there is no mention of this in the Qur'an. In this chapter, Jomier also discusses the basic teachings of the Qur'an and the history of its collection, but once again he fails to base his arguments on defined sources. For example, he makes a baseless claim when he says, "And two centuries later the text was definitively established" (p. 5).

In "Makkah and the Early Days of Islam," Jomier endeavors to present a short history of the Prophet in Makkah, but he often relies on the weakest hadith, and sometimes even misquotes it. For example, while discussing the first revelation, he writes, "It was during one such retreat, around the year 610, when he was about forty years old, that he had a dream or, to use the terms employed by Bukhari, a true vision in his sleep. According to this tradition, the angel came and said to him: 'Recite ..."' (p, 16). Yet the tradition in Bukhari does not mention vision or sleep! Throughout the chapter Jomier also displays a strong inclination toward interpreting the early days of the revelation in the light of old Judeo-Christian sects and the customs of soothsayers in Arabia. $\mathrm{He}$ even admits to his limited knowledge when he says, "We know nothing at all about the relations between Muhammad and the monotheists in Makkah before the early days of Islam" (p. 15). Yet his obsession with this notion is clear in his repeated (and sometimes out of context) references to the pre-Islamic 
Christians and monotheists of Makkah - almost as if he is trying to use repetition as a substitute for evidence.

In the third chapter, titled "Hymns to God the Creator," the author discusses the praises to God under seven subheadings. Here, once again, we find that while making comparisons between the Qur'an and biblical hymns, Jomier's conclusions often present the Qur'an as lacking in sophistication. For example he says, "In the Qur'an there is none of the exuberant imagination found in Psalm 104" (p. 27), and "The restraint of the style means that comparatively few creatures are referred to in the Qur'an. If one wanted to find a zoo or a botanical garden with the plants and animals mentioned in the different suras, one would not end up with a very large park" (p. 27). The reason for the latter, rather peculiar remark can be understood only in the light of the insinuation made by some people that the Qur'an was a product of the Arab mind and culture, which existed in an environment deprived of rich vegetation and with limited varieties of livestock.

The fourth theme, "Adam, Father of Humankind," deals with the concept of man in the Qur'an and refers to the story of Iblis-Satan extensively. Jomier totally ignores the possibility of Iblis being a jinn and has chosen the opinion most suitable to the Judeo-Christian concept of Satan as a "fallen angel." This tendency is further demonstrated when he deals with Satan's refusal to prostrate to Adam. Indeed, in the absence of evidence, the author cites an assumption made by the writer Elizabeth van Speyer that "the scene is connected with the Christian reinterpretation of Jewish traditions about the angels' rebellion that writers relate to the union between angels and the daughters of men" (p. 45).

In the chapter etitled "Abraham, the Muslim," the author contradicts himself by stating that "the history of humanity begins with Adam" (p. 52) as opposed to his previous contention in chapter 1 that the history of humanity began with the disobedience of the first couple (Adam and Eve) and their expulsion from the earthly paradise. The story of Abraham is told with some degree of justice and would read well had it not been for sporadic condescending remarks. For example, on page 61 , while counting the number of places of worship linked with the memory of Abraham mentioned in Genesis, and failing to find a reference to the Ka'bah, the author seems to be sympathetic by suggesting a hypothetical Jewish tradition to explain its association to the memory of Abraham. However, if one looks at the first sentence of the following paragraph, the subjective nature of the approach is evident: "Merely because the Qur'an reports it, this tradition assumes an absolute value for the Muslim." This kind of sarcasm is, sadly, employed regularly. For instance, in chapter 7, he writes, "In spite of the surprise of Christians, who find nothing of the sort in the Gospels 
they possess, this statement presents no difficulty for believers [i.e., Muslims]: since the Qur'an says so, it must be true" (p. 89). Not only is it quite astonishing that the "surprise of the Christians" should be a consideration, but one also notices the double standard applied, as the author uses the Bible as an absolute reference by which to judge the veracity of the Qur'an. In any case, the mere repetition of Muslim acceptance of the Qur'an as the truth is pointless, for the author said himself in chapter 1: "For a Muslim, the Qur'an is a book whose author is God Himself. ... The Muslim therefore regards the Qur'an as the most sacred object on earth, God's supreme gift to humanity" (p. 1).

Another example of the author's subjective style is his frequent use of rhetorical questions. For instance, instead of saying that the Qur'an does not give any geographical information about anyone, he says: "Does the Qur'an provide geographical or historical information that would enable us to place Abraham in his milieu and age? Actually, it is pointless to look for facts of this kind, for like many other Qur'anic figures, Abraham exists beyond time and space. The reader does not know where he comes from or where he is bound for" (p. 57).

The sixth theme, titled "The Prophets who were 'Saved,"' examines the stories of the Qur'anic prophets with the usual comparison to biblical sources. Where it is not possible to maintain the subtle accusation of plagiarism - as in the case of the three prophets of Midian, Hud, Salih, and Shu'ayb, who are not mentioned in the Bible - the author assumes that "these [stories] must have been old Arabian traditions which the Qur'an had taken up and used as arguments to reinforce the authority of the prophets" (p. 73).

In the chapter "Jesus, Son of Mary," Jomier attempts to elaborate on his earlier contention that the Qur'anic approach to dealing with prophets is "beyond time and place," meaning removed from human reality. He writes, "The prophet represents an example of human perfection that in principle rules out any idea of the fall, even as a starting point for the finest example of repentance. ... The Muslim relies on the terseness and silences of the Qur'an" (p. 82). He dwells particularly on the issues that are usually popular with Orientalists, such as Jesus as the "Word of God," Spirit, and his being "taken to Himself" as meaning that he died. The author also mentions several contemporary Christian thinkers who are trying to prove the divinity of Christ from the Qur'an (p. 90).

The eighth chapter, which deals with the Muslim community in Makkah and Madinah, makes yet another reference to Waraqa ibn Nawfal and others (p. 100 ) in order to maintain the underlying theme of the book, which is that most Qur'anic teachings are probably plagiarized from Judeo-Christian sources.

Finally, in chapter 9, titled "Arguments and Persuasion," Jomier examines the effects of the Qur'an on the human psyche and tries to analyze it in terms 
of its literary devices. He draws attention to the "simplicity of Qur'anic arguments and their vivid and concrete character" (p. 109) and writes that "this simplification is effective in reducing primitive paganism to silence. It is equally effective in the face of neo-paganism like the deification of material things, money and the state" (p. 111). He alludes to possible comparisons with "popular literary genres (or modem avant-garde ones)" (p. 109), as he did in earlier chapters, trying to explain away certain styles of the Qur'an as well-known techniques used by storytellers (p. 15) and even modem novelists. He says, "The reader's perplexity in the face of uncertainty produces a feeling similar to that engendered by 'modem' novels in the West today, a kind of disorientation" (p. 19). Eventually, though, the author is forced to acknowledge the fact that "it is not only the intellect that is affected, but all the fibers of one's being. The Quran itself pictures the power that it exerts when it describes how, during its recitation, the skin reacts under a kind of religious spell" (p. xii). The final paragraph of his conclusion reveals the hopelessness of the task he set himself: "It is difficult to understand the fascination that the Qur'an exerts without mentally putting oneself in the place of the Muslim, who finds God when he recites it, looks to it for guiding principles, and for whom the Qur'an is the presence of God" (p. 124).

Riad Nadwi

Rector

Dar al Uloom Oxford 